\title{
Development and nutritional evaluation of infant complementary food from maize (Zea mays), soybean (Glycine max) and Moringa oleifera leaves
}

\author{
Nwosu Odinakachukwu I. C. ${ }^{1}$, Nnam Ngozi N. ${ }^{2}$, Ibeziako Ngozi $^{3}$, Maduforo Aloysius N. ${ }^{4}$ \\ ${ }^{1}$ Department of Nutrition and Dietetics, University of Nigeria Teaching Hospital Ituku/Ozalla, Enugu State, Nigeria \\ ${ }^{2}$ Department of Home Science, Nutrition and Dietetics, University of Nigeria Nsukka, Enugu State, Nigeria \\ ${ }^{3}$ College of Medicine, University of Nigeria Enugu Campus, Enugu State, Nigeria \\ ${ }^{4}$ Department of Nutrition and Dietetics, PMAN International Health Services, Abuja FCT, Nigeria
}

\section{Email address:}

nodinakachukwu@yahoo.com (Nwosu O. I. C.)\

\section{To cite this article:}

Nwosu Odinakachukwu I. C., Nnam Ngozi N., Ibeziako Ngozi, Maduforo Aloysius N.. Development and Nutritional Evaluation of Infant Complementary Food from Maize (Zea Mays), Soybean (Glycine Max) and Moringa Oleifera Leaves. International Journal of Nutrition and Food Sciences. Vol. 3, No. 4, 2014, pp. 290-299. doi: 10.11648/j.ijnfs.20140304.19

\begin{abstract}
Aims: This study developed and evaluated infant complementary food made from locally available foods to which was feed to infants 6-12 months of age. The study was aimed to: develop infant complementary food from yellow maize (Zea mays), soybean (Glycine max) and green leafy vegetables (Moringa oleifera), determine the nutrient composition of the complementary food, determine the acceptability of the food and determine the nutritional quality of the infant complementary food in children. Study Design: The study made use of both food samples and human samples. It investigated the nutrient content of the diet blend and conducted a test trial with children. Methodology: All the food materials were milled into fine flours. The proximate, energy, mineral and $\beta$-carotene contents of the flours were determined using standard methods. The flours were used to develop 2 blends in ratios of 60:40 (control) and 60:30:10 (test) maize + soybean and maize + soybean + Moringa oleifera leaves respectively. The 2 blends provided $10 \%$ protein. The blends were used to prepare gruels whose sensory evaluation was conducted using 30 mothers. The gruels were fed to 2 groups of infants in the Holy Child Motherless Babies Home in Enugu for 12 weeks. Result: Protein (15. 15\% vs 11.36.2) and carbohydrate $(47.15 \%$ vs $55.73 \%)$ of the blends differed $(\mathrm{P}<0.05)$. Ash, fat, crude fiber and energy of both blends were comparable $(\mathrm{P}>0.05)$. The Iron and zinc contents of the blends were similar $(\mathrm{P}>0.05)$. $\beta$-carotene and calcium of the test blend were higher $(\mathrm{P}<0.05)$ than that of control blend. The blends had comparable $(\mathrm{P}>0.05)$ flavor, texture and acceptability, however, it differed in colour $(\mathrm{P}<0.05)$. The body weight of the subjects increased significantly $(\mathrm{P}<0.05)$ after feeding the test diet. Length, head circumference and chest circumference increased slightly $(\mathrm{P}>0.05)$ in the 2 groups after feeding. Haemoglobin $(\mathrm{Hb})$ was higher $(12.34 \%$ vs $8.96 \%)$ in the group fed test blend and unsaturated iron binding capacity (UIBC) and total iron binding capacity (TIBC) increased much more in the subjects fed control blend. Conclusion: Moringa oliefera fortification of the infant complementary food improved the nutrient quality. Shade-dried Moringa oleifera leaves had good nutrient profile and general acceptability. Incorporation of pulverized Moringe oleifera leaves in infants' food could diversity food intake, ensure food and nutrition security.
\end{abstract}

Keywords: Development, Nutritional Evaluation, Infant, Complementary Food, Zea Mays, Glycine Max, Moringa Oleifera Leaves

\section{Introduction}

The importance of nutrition as a foundation for healthy development is often underestimated ${ }^{[1]}$. Poor nutrition leads to ill-health and ill-health contributes to further deterioration in nutritional status. These effects are most dramatically observed in infants and young children ${ }^{[1]}$. They suffer the highest risk of disability and death associated with it. In Nigeria, studies have indicated a high prevalence of malnutrition ${ }^{[1]}$. Report revealed that $54 \%$ of all children mortality in Nigeria was attributed directly or 
indirectly to malnutrition ${ }^{[1]}$. It was equally observed that in Nigeria, $31 \%$ of children under-five have been reported underweight, $16 \%$ wasted and $34 \%$ stunted ${ }^{[2]}$.Malnutrition is associated with increased morbidity ${ }^{[2]}$. About $30-40 \%$ of deaths in pre-school age children in Nigeria are associated with malnutrition ${ }^{[3]}$. In Nigeria Food Consumption and Nutrition Survey and Nigeria Demographic and Health Survey observed that in Nigeria, the rate of stunting among under-five children exceeds $40 \%$, wasting about $90 \%$ and underweight $25 \%$. At least $60 \%$ of children who die from different causes have malnutrition as anderlying cause $[4,5]$.

The causes of malnutrition are many and complex. Inappropriate breastfeeding and complementary feeding practices coupled with high rates of infectious diseases are the major immediate cause of malnutrition during the first two years of life ${ }^{[6]}$. Reports show that the rate of exclusive breastfeeding for 6 months is still very low in Nigeriabetween $15 \%$ and $17 \%{ }^{[4,5]}$. Children who are not breastfed have repeated infections, experience poor growth and are almost six times more likely to die by the age of one month than children who receive at least some breast milk. From six months onwards, when breast milk alone is no longer sufficient to meet all nutritional requirements, infants enter a particularly vulnerable period of complementary feeding. They make a gradual transition to eating family foods. The incidence of malnutrition rises sharply between this age and 18 months in most countries ${ }^{[6,7,8]}$. The deficits acquired at this age are difficult to compensate for later in childhood. Infants therefore, need nutritionally adequate energy-dense complementary foods in addition to breast milk ${ }^{[7]}$.

Unfortunately, complementary feeding begins too early or too late, and foods are often nutritionally inadequate and unsafe ${ }^{[9]}$. This results into protein-energy malnutrition (PEM) and micronutrient deficiency (hidden hunger). Report showed very high levels of iron deficiency anemia among infants ${ }^{[4,5]}$. Poor absorption of iron, parasitic infestation and disease are equally contributory factors. Often, the traditionally complementary foods consist mainly of porridges made from un-supplemented cereals and starchy food like sorghum, maize and millet ${ }^{[10]}$. The foods are mostly inadequate in energy, protein and micronutrients ${ }^{[11,12]}$.

WHO recommended the major criteria for a good-quality complementary food to be adequate protein content, high energy value per unit of food volume, soft texture, low fiber content, adequate vitamins and minerals and absence of anti-nutritional factors $[10,13,14]$. To this effect, the formulation and development of nutritious complementary foods from local and readily available foods had received considerable attention in many developing countries ${ }^{[15-21]}$. However, the development of low cost, high protein and micronutrient dense food supplements for infants is a constant challenge for developing countries ${ }^{[22]}$. This is particularly important in counties like Nigeria where malnutrition is still common.

Staple foods such as maize, soybean and iron-rich green leafy vegetables e.g. Moringa Oleifera ("drum stick" or
"Okwe Oyibo") could be good for the development of good complementary food. The thrust of this study is to develop and determine the nutrient value, and acceptability of maize-based complementary food fortified with Moringa oleifera.

\section{Methodology}

\subsection{Study Area}

The study was carried out at Holy Child Motherless Babies Home, Ogui-Enugu, Nigeria. The Holy Child Motherless Babies Home is owned by the Catholic Diocese of Enugu. It is situated within Holy Ghost Cathedral compound backing the Enugu-Port Harcourt railway line. It is bounded on the South by Mother of Christ Specialist Hospital, on the North by Ave Maria Dentistry and facing St Monica's Vocation School on the West. It is presently managed by the Sisters of Daughters of Mary, Mother of Mercy Congregation and has accommodation capacity for more than 40 babies (the average monthly baby occupancy rate is 35$)$.

A written permission was obtained from the matron incharge (a Reverend Sister) by the researcherss. The consent of the mothers used for the sensory evaluation was obtained after oral interview. Ethical clearance was obtained from the Health Research Ethical Committee University of Nigeria Teaching Hospital (UNTH) Ituku-Ozalla Enugu, Nigeria.

\subsection{Materials}

Yellow maize (Zea mays) seeds, soybean (Glycine max) seeds and Moringa oleifera (Drum stick) leaves were used for the study. The maize and soybean were purchased in bulk from New Market, Enugu. The Moringa oleifera leaves were obtained from trees in a family farm in the Government Reserved Area (GRA) Enugu.

\subsection{Preparation of Materials}

\subsubsection{Maize}

Eighteen kilogrammes $(18 \mathrm{~kg})$ of yellow maize were hand-picked and cracked with a laboratory harmer-mill (Thomas Willey, mold ED-5) to separate the bran from the grain. The cracked grains were winnowed to remove the bran. The seeds were then steeped in water in a ratio of $1: 3$ weight of grain/volume of water $(\mathrm{w} / \mathrm{v})$ and allowed to ferment at $28 \pm 2{ }^{\circ} \mathrm{C}$ (ambient temperature) for $48 \mathrm{~h}$ by the micro flora inherent in the seed. The water was changed after $24 \mathrm{~h}$ to remove sour taste. At the end of the fermentation period, the grains were drained, dried in hot air oven at $55^{\circ} \mathrm{C}$ for about $10 \mathrm{~h}$, dry milled and packaged in polythene bags as fermented maize flour and stored frozen at a temperature of $-4^{\circ} \mathrm{C}$ until when used.

\subsubsection{Soybean}

Fifteen kilogrammes $(15 \mathrm{~kg})$ of soybean seeds were cleaned by hand-picking. The samples were boiled with water in the ratio of 1:3 weight of seeds/volume of water 
$(\mathrm{w} / \mathrm{v})$ for $1 \mathrm{~h}$. The grains were dehulled manually and dried in a hot air oven (Gallenkamp BS oven, model 320 ) at $55^{\circ} \mathrm{C}$ for about $10 \mathrm{~h}$ and milled in a laboratory harmer mill (Thomas Willy, Model ED-5) to a fine flour (70mm mesh screen). The flour was packaged in a polythene bag and stored frozen at $-4^{\circ} \mathrm{C}$ until used.

\subsubsection{Moringa Oleifera Leaves}

Eight kilogrammes $(8 \mathrm{~kg})$ of fresh Moringa oleifera leaves were plucked, washed and drained, shade-dried, pulverized and packaged in polythene bag and stored in the freezer at $-4^{\circ} \mathrm{C}$ until used.

\subsection{Chemical Analysis}

\subsubsection{Proximate Analysis}

\subsubsection{Determination of Moisture Content}

Determination of moisture content was done using AOAC method ${ }^{[23,24]}$. About two grammes (2 g) of sample were weighed into a preweighed clean weighing/drying dish provided with easily removable lid. The dish was uncovered and placed in a well-ventilated oven maintained at $103^{\circ} \mathrm{C} \pm 2^{\circ} \mathrm{C}$. After $16 \mathrm{~h}$, the lid was replaced and transferred to a desiccators at room temperature to cool, and quickly weighed to $0.1 \mathrm{~g}$ and placed in the oven for another two h. Steps 4 and 5 were repeated until the mass was decreased between successive weighing not exceeding $0.06 \mathrm{mg}$ per $\mathrm{g}$ of sample (fresh weight basis). The loss in weight represented percent moisture content as follows:

$\begin{array}{lll}\% \text { moisture } & =\quad \frac{\mathrm{M}_{1}-\mathrm{M}_{2}}{\mathrm{M}_{1}-\mathrm{M}_{0}} \times \frac{100}{1} \\ \text { Where Mo } & =\quad \text { weight of dish and lid }\end{array}$

$\mathrm{M}_{1} \quad$ = weight in $\mathrm{g}$ of dish, lid and sample before drying

$\mathrm{M}_{2} \quad$ = weight in $\mathrm{g}$ of dish, lid and sample after drying

Note that $\mathrm{M}_{1}-\mathrm{M}_{\mathrm{o}}=$ weight of sample prepared for drying

\subsubsection{Determination of Ash Content $(A O A C \text {, })^{[23,24]}$}

Crucible was washed and dried in an air hot oven, cooled in a dessicator and reweighed. About $2 \mathrm{~g}$ of dried sample were weighed into the empty porcelain crucible previously ignited over a hot plate in the fume cupboard to char organic matter. The crucible was placed in a muffle furnace maintained at a temperature of $600^{\circ} \mathrm{C}$ for $6 \mathrm{~h}$, transferred to a dessicator, cooled and reweighed immediately.

$\%$ Ash $=$

(weight of crucible + ash) - wt of empty crucible $\times \underline{100}$ Sample weight

1

\subsubsection{Determination of Crude Fibre, Joselyn Method ${ }^{[23,}$} 24]

About $2 \mathrm{~g}$ of the sample were weighed into a $600 \mathrm{ml}$ long beaker. $200 \mathrm{ml}$ of hot $1.25 \% \mathrm{H}_{2} \mathrm{SO}_{4}$ was added. Beaker was placed on digestion apparatus with preheated plates, boiled, refluxed for 30mins and filtered through Whiteman GF/A paper by gravity. The beaker was rinsed with distilled water. The residue was washed on the paper with distilled water until the filtrate was neutral. The residue was transferred from the paper back to the beaker containing $200 \mathrm{ml}$ of hot $1.25 \% \mathrm{NaOH}$. Steps 4 and 5 were repeated. The paper with residue was transferred into a crucible, dried at $100^{\circ} \mathrm{C}$ overnight, cooled in a dessicator and reweighed (weight $\mathrm{A}$ ). The samples were put in furnace at $600^{\circ} \mathrm{C}$ for $6 \mathrm{~h}$, cooled in a dessicator and reweighed (weight $\mathrm{B}$ ). The loss in weight during incineration represents the weight of crude fibre.

$\%$ crude fibre $=\underline{(\text { weight } \mathrm{A})-(\text { weight } \mathrm{B})} \times \underline{100}$

$$
\text { Sample weight } \frac{100}{1}
$$

\subsubsection{Determination of Fat (AOAC,) Method $^{[23,24]}$}

Soxhlet system HT2 method was adapted. The sample was ground and dried and $2 \mathrm{~g}$ were loaded in thimble and plugged with cotton wool. The thimble was dried and inserted into the Soxhlet HT. Extraction cups were dried and weighed (with boiling chips) and $25 \mathrm{ml}$ of the solvent was added into each cup. The cup was inserted into the soxhlet HT. The extraction cups were dried and weighed (with boiling chips. $25 \mathrm{ml}$ of the solvent was added to the solvent in each cup. The cup was inserted into the Soxhlet HT and extracted for $15 \mathrm{mins}$ in boiling position and for 30mins in "rinsing position". The solvent was evaporated; the cups were released and dried at $100^{\circ} \mathrm{C}$ for $30 \mathrm{mins}$. The cups were cooled in a dessicator and reweighed.

$\%$ fat $/$ oil $=\quad \frac{W_{3}-W_{2}}{W_{1}} \times \frac{100}{1}$

Where $\mathrm{W}_{3}=$ weight of the cup with the extraction oil; $\mathrm{W}_{2}=$ weight of the empty cup; $6.25=$ protein conversion factor; $\mathrm{W}_{1}=$ Weight of the sample

\subsubsection{Determination of Protein}

Digestion: Protein content was determined using microKjeldahl method of AOAC ${ }^{[23,24]}$. About $1 \mathrm{~g}$ of each sample was weighed into a $100 \mathrm{ml}$ micro-Kjeldahl digestion flask. About $1 \mathrm{~g}$ of copper sulphate and $10 \mathrm{~g}$ sodium sulphate were added to the flask and thoroughly shaken and placed on the digestion rack in an inclined position. The sample in the flask was digested by heating in a flame chamber until frothing ceased. The temperature was increased, allowed to boil for about one hour until the colour changed to bluish green. The clear digested sample was allowed to cool.

Distillation: Some distilled water was added to the digested sample with a wash bottle to $100 \mathrm{ml}$ in a $100 \mathrm{ml}$ volume metric flask. A- $10 \mathrm{ml}$ of the digest was pipette and transferred into a micro-Kjeldahl distillation flask followed by the addition of $60 \mathrm{ml}$ of $60 \%$ sodium hydroxide $(\mathrm{NaOH})$ solution. The flask was immediately fixed to the splash head of the distillation apparatus. A-4\% boric acid was added into a $100 \mathrm{ml}$ receiving conical flask, 2 drops of methyl red indicator was added, in such a way that the outlet of the adopter of the delivery tube was extended under the surface of the boric acid solution. The mixture was heated to liberate ammonia into the receiving conical flask containing $100 \mathrm{ml}$ boric acid and the indicator until yellowish green colour distillate was obtained.

Titration: The distillate was titrated with $0.1 \mathrm{~N}$ hydrochloric acid $(\mathrm{HCl})$ until the end point of pink 
colouration was obtained. The percentage $(\%)$ protein was calculated thus:

$$
\begin{aligned}
& \text { Protein }(\%)=\frac{\mathrm{T} \times 0.0014 \times 6.25}{\mathrm{Wt} \text { of the sample }} \times \frac{100}{1} \\
& \text { Where } \mathrm{T}=\text { titre value of the sample } \\
& 0.0014=\text { correction factor of the acid }
\end{aligned}
$$

\subsubsection{Carbohydrate Determination}

This was determined by difference method. The summation of all the proximate values was subtracted from 100\%. Thus:

$\%$ carbohydrate $=100 \%-(\%$ crude protein $+\%$ fat $+\%$ ash $+\%$ Crude fibre $+\%$ moisture)

\subsubsection{Energy Determination}

Energy was determined by the "Atwater factor". The energy value of the samples were calculated by multiplying the values for fat, $\mathrm{CHO}$ and protein with 17:37:17 the "Atwater factors" respectively.

$\begin{array}{lll}\text { Where protein } & = & 17 \mathrm{KJ} / \mathrm{g} \\ \text { fat } & = & 37 \mathrm{KJ} / \mathrm{g} \\ \mathrm{CHO} & = & 17 \mathrm{KJ} / \mathrm{g}\end{array}$

\subsubsection{Vitamin Analysis}

Pro-vitamin A (beta carotene) was determined using AACC method ${ }^{[25]}$. A $10 \mathrm{~g}$ of each sample was weighed into a $250 \mathrm{ml}$ conical flask and $50 \mathrm{ml}$ of $50: 50$ acetones was added. This was allowed to stand for two hours (2h) with occasional shaking and filtering. The filtrate was measured and equal volume of saturated $\mathrm{NaCl}(50 \%)$ was added to wash the filtrate (i.e. carotene extract). The mixture was shaken, transferred to a separating funnel, and the layer of the extracted carotene was removed. The supernatant (upper layer) was washed again with equal volume of $100 \%$ potassium trioxocarbonate (IV) $\left(\mathrm{K}_{2} \mathrm{CO}_{3}\right)$, separated and finally washed with about $10-20 \mathrm{ml}$ of distilled water. Water carotene was separated and the extracted carotenoid (either beta carotene or lycopene) was collected. The absorbance was read in a spectrophotometer at $326 \mathrm{~nm}$ wavelength using 50:50 acetone low boiling petroleum ether solution as blank. The pro-vitamin A content was calculated as follows:

$$
\text { Potency (units/g) }=1900 \times E_{1 \mathrm{~cm}}^{1 \%} \text { at } 328 \mathrm{~nm}
$$

The following correction was applied if the maximum lies in the same range, but the relative extensions are not within 0.02 .

$$
E_{328}(\text { Corrected })=3.52\left(2 E_{328}-E_{316}-E_{340}\right)
$$

\subsubsection{Mineral Analysis}

The method described by Ranjiham and Gapal ${ }^{[26]}$ was used to determine calcium, iron and zinc. About $1 \mathrm{~g}$ of each sample was weighed into $100 \mathrm{ml}$ round bottom flask. Five millilitres $(5 \mathrm{ml})$ of perchloric acid was added and heated over electric heater in a fume chamber until the solution became colourless. Each of the solution was made up to $10 \mathrm{ml}$ mark with distilled water and the diluted sample was set aside for further studies. The iron, zinc and calcium were analyzed using absorption spectrophotometric method.

\subsection{Screening Exercise}

A Pediatrician from University of Nigeria Teaching Hospital (UNTH) Ituku-Ozalla, Enugu examined the subjects for congenital and chronic infections. She equally conducted clinical examination to detect any clinical signs suggestive of malnutrition. Twenty (20) babies who met all the experimental requirements were taken.

\subsubsection{Inclusion Criteria for both Groups (Control and Test Groups)}

- $\quad$ Age range of 6 to 12 months

- Screened and confirmed healthy

- No congenital disorder

- Has been started on complementary food.

\subsubsection{Exclusion Criteria for both Groups (Control and Test Groups)}

- Less than 6 months and more than 12 months of age

- Presence of infection

- Presence of congenital disorder

- Incapable of swallowing complementary food.

\subsection{Characteristics of the Subjects}

\subsubsection{Sex and Age Distribution of the Subjects Fed the Diets}

Out of the twenty (20) subjects investigated, ten (10) were randomly picked and fed the test diet and the remaining ten (10) were fed control diet. Two of those fed test diet bluntly refused to eat. They kept crying and vomiting each time they were fed the diet. The two subjects were eventually dropped and eight (8) remained till the end of the investigation. Two (2) subjects also dropped from control diet due to cough and malaria that precipitated intermittent vomiting.

Table 1. Sex and age distribution of subjects fed the diets

\begin{tabular}{llllll}
\hline Diets & Sex & Frequency & Age (months) & & \\
\hline & & & $6-8$ & $9-11$ & 12 \\
Control diets & $\mathrm{M}$ & $3(37.5 \%)$ & $2(66.66 \%)$ & $1(33.33 \%)$ & - \\
(Group 1) & $\mathrm{F}$ & $5(62.5 \%)$ & $2(40 \%)$ & $2(40 \%)$ & $1(20 \%)$ \\
Total & & $8(100 \%)$ & & & $1(25 \%)$ \\
Control diets & $\mathrm{M}$ & $4(50 \%)$ & $2(25 \%)$ & $1(25 \%)$ & $1(25 \%)$ \\
(Group 1) & $\mathrm{F}$ & $4(50 \%)$ & $2(25 \%)$ & & \\
Total & & $8(100 \%)$ & & & \\
\hline
\end{tabular}

Key: $\mathrm{F}=$ female. $\mathrm{M}=$ male 
Out of the remaining 8 in group 1, $3(37 \%)$ were males of which 2 were between 6-8 months of age and 1 was between $9-11$ months. Five (5) were females out of which 2 were $6-8$ months of age, 2 under $9-11$ months and 1 was 12 months old. There were 4 males in group 2 and out of this number $2(50 \%)$ were between $6-8$ months of age, $1(25 \%)$ each fell under $9-11$ and 12 months of age respectively. The same was applicable to females.

\subsubsection{Formulation of the Diets (Blends) Used in Feeding Trial}

Two diets were formulated based on the processed flours to provide $10 \%$ protein in the following ratios: $60: 30: 10$ (maize: soybean: Monringa oleifera leaves), and 60:40 (maize: soybean) flours. The control diet contained 60\% maize and soybean contributed $40 \%$ protein to the diet. The test diet contained $60 \%$ maize, soybean contributed $30 \%$ and Moringa oleifera contributed $10 \%$ of the total protein, respectively (Table 3.3).

Table 2. Composition of the formulated diets (blends) used in feeding trial

\begin{tabular}{llll}
\hline Diets & Maize (g) & Soybean $(\mathrm{g})$ & Moringa oleifera leaf $(\mathrm{g})$ \\
\hline 1; (60:40) Maize + soybean & 600.00 & 80.00 & - \\
2; (60:30:10) maize + Soybean + Moringa oleifera leaf & 600.00 & 60.00 & 25.00 \\
\hline
\end{tabular}

\subsection{Preparation of Gruel}

\subsubsection{Recipes for the Gruel}

Water was allowed to boil and the blend was added, stirred and cooked for about 10 to 12 minutes. The gruel was allowed to cool before it was fed to the babies.

Table 3. Recipes for the gruel

\begin{tabular}{lll}
\hline Diet & Components & Quantity \\
\hline \multirow{2}{*}{1} & Blend & $227 \mathrm{~g}$ \\
& Water & $250 \mathrm{mls}$ \\
2 & Blend & $228 \mathrm{~g}$ \\
& Water & $251 \mathrm{mls}$ \\
\hline
\end{tabular}

Key: Diet $1=$ Control diet, Diet $2=$ Test diet

\subsection{Sensory Evaluation}

Seven (7) Dietitians from UNTH Ituku-Ozalla Enugu were selected to pre-test the diets. A 9-point hedonic scale was used to determine the organoleptic attributes and acceptability of the complementary foods. The number "9" represented 'like extremely', '1' represented 'dislike extremely'. The observations and suggestions made by the Dietitians were used to improve on the preparation of the gruel.

A total of 30 mothers were selected for the sensory evaluation. Twenty of them were selected randomly from the mothers attending Mother and Child Health Clinic (MCHC) UNTH Ituku-Ozalla, and the remaining 10 were selected from the care-takers in the Motherless Babies Home. These mothers voluntarily accepted to participate after thorough detailed discussion session and interview. Four (4) interns from the Department of Nutrition and Dietetics UNTH conversant with sensory evaluation were selected to assist in the exercise. They assisted in interpreting and filling the questionnaire.

The researchers prepared the diets in form of gruel. These consist of 2 diets (test diet and control diet). The diets were put in labeled plates. Every mother was given 2 spoons with which she tasted the different samples. The assistants provided them with water which they used in rinsing their mouth in between the tasting of different samples to prevent carry over effect of the tastes of the diets. The exercise was supervised by the researchers.

\subsection{Anthropometric Measurements}

Weight of the subjects was obtained using British infant weighing scale (WAYMASTER). The subjects were placed on the scale nude and their weights recorded to the nearest $0.1 \mathrm{~kg}{ }^{[27]}$. This was done before and after feeding of the subjects.

Length of the subjects was collected with the aid of infantometer to the nearest $0.5 \mathrm{~cm}^{[27]}$. The infantometer had a fixed headboard, a moveable footboard and a rule attached at one side was placed on a flat table. One assistant held the crown of the subject's head against the headboard so that the external auditory meatus and the lower margin of the eye orbit were aligned perpendicular to the table. The second assistant griped both ankles of the subject with one hand and positioned the heels firmly against the footboard, which was manipulated with the other hand. The knees were slightly fixed, pressed down on the table with the lateral edge of the hand. The researchers took record of the recumbent length to the nearest $0.1 \mathrm{~cm}^{[27]}$

Head circumference was measured with a narrow and non-stretchable Chinese measuring tape (superior tailoring rule). The tape was placed to cross the forehead just above the supraorbital ridges, passed around the head at the same level on both sides of the occiput. It was moved up and down to obtain the maximum circumference to the nearest $0.1 \mathrm{~cm}$.

Chest circumference was measured using measuring tape. The tape was placed round the chest of the subject to pass through the nipples of the two breasts. The chest circumference was obtained to the nearest $0.1 \mathrm{~cm}$.

\subsection{Blood Sample Collection}

Laboratory technologist was employed to collect the blood samples of the subjects. The blood sample for each subject was collected into two (2) different sample bottles. 
One contained $2 \mathrm{ml}$ of blood and the other one contained anti-coagulant K-EDTA (Potassium Ethylene Diamine Tetracetic acid) added to $5 \mathrm{ml}$ of blood. The K-EDTA was necessary to avoid any interface with haemoglobin $(\mathrm{Hb})$ estimation. The caretakers of the Motherless Babies held the subjects in turn during collection of the blood samples. The blood samples were collected before and after the feeding trail and in each case, it was ensured that sample reached the laboratory within $2 \mathrm{~h}$ of collection to avoid spoilage.

\subsection{Feeding}

Group 1 was fed diet 1 (control diet) and group 2 was fed diet 2 (test diet). The groups were fed the test and control diets during breakfast while they ate their normal food during other meal times. The researchers were at the research home early $(6.30 \mathrm{am})$ every morning to prepare the diet and fed the subjects with the aid of the research assistants. The amount taken at each meal was recorded by the researchers as well as the remaining and/or the vomited ones.

\subsection{Biochemical Analysis of Blood Samples}

Methods described by Dacie and Lewis was adopted to determine the haemoglobin, serum Iron, Serum calcium, serum zinc and unsaturated iron binding capacity (UIBC) of the samples ${ }^{[28]}$.

\subsection{Statistical Analysis}

The mean and standard deviation of the samples were calculated. Student T-test was used to separate and compare mean $(\mathrm{P}<0.05)$.

\section{Results}

Table 4 presents the proximate and energy composition of the formulated diets (blends) (\%). The moisture content was $10.46 \%$ in diet 1 (control diet) and $10.17 \%$ in diet 2 (test diet). The protein levels were $13.57 \%$ in the control diet and $10.14 \%$ in the test diet. The test diet had fat of 24 . $41 \%$ and control had $27.44 \%$. Ash level was $3.07 \%$ and $2.77 \%$ in diet 1 and 2 respectively. Crude fibre was $3.25 \%$ in diet 1 and $2.46 \%$ in diet 2. Carbohydrate was $42.22 \%$ in diet 1 and $50.06 \%$ in diet 2. Energy level for diets 1 and 2 were $1,686 \mathrm{KJ}$ and $1,641 \mathrm{KJ}$ respectively.

Table 4. proximate and energy composition of formulated diets (\%)

\begin{tabular}{lll}
\hline Nutrient & Diet 1 & Diets 2 \\
\hline Moisture & $10.46 \pm 0.02$ & $10.17 \pm 0.02$ \\
Crude protein & $13.57 \pm 0.02$ & $10.14 \pm 0.01$ \\
Fat & $27.44 \pm 0.01$ & $24.41 \pm 0.02$ \\
Ash & $3.07 \pm 0.02$ & $2.77 \pm 0.01$ \\
Crude fibre & $3.25 \pm 0.01$ & $2.46 \pm 0.01$ \\
CHO & $42.22 \pm 0.05$ & $50.06 \pm 0.01$ \\
Energy (KJ) & $1,686 \pm 0.47$ & $1,641 \pm 0.47$ \\
\hline
\end{tabular}

Key: Diet $1=$ Control diet, Diet $2=$ Test diet
Table 5 presents the proximate and energy composition of the formulated diets (blends) used on dry matter basis $(\%)$. The protein content of both diets differed $(\mathrm{P}<0.05)$ (15.15 vs. $11.30 \%)$. The ash, fat and crude fibre of the diets were comparable $(\mathrm{P}>0.05)$. Carbohydrate differed $(\mathrm{P}<0.05)$ with diet 1 having $47.15 \%$ and diet 2, 55.73\%. Diet I had energy level of $1,877 \mathrm{KJ}$ and diet 2 had $1,827 \mathrm{KJ}$.

Table 5. Proximate and energy composition of the complementary diets (dry matter basis; \%).

\begin{tabular}{lll}
\hline Nutrient & Diet 1 & Diet 2 \\
\hline Protein & $15.15^{\mathrm{a}}$ & $11.30^{\mathrm{b}}$ \\
Fat & $30.64^{\mathrm{a}}$ & $27.20^{\mathrm{a}}$ \\
Ash & $3.43^{\mathrm{a}}$ & $3.08^{\mathrm{a}}$ \\
Crude fibre & $3.63^{\mathrm{a}}$ & $2.74^{\mathrm{a}}$ \\
CHO & $47.15^{\mathrm{b}}$ & $55.73^{\mathrm{a}}$ \\
Energy $(\mathrm{KJ})$ & $1,877^{\mathrm{a}}$ & $1,827^{\mathrm{a}}$ \\
\hline
\end{tabular}

Key: Diet 1: Control diet: Maize and soybean (60:40) ; Diet 2: (test diet) maize, soybean and Moringa oleifera (60:30: 10); Value with the same superscript (a-a) for the same nutrient are statistically similar $(\mathrm{P}>0.05)$ and those with different superscripts $(a-b)$ for the same nutrient are different.

Table 6 shows the calcium, iron, zinc and $\beta$ - carotene composition of the formulated diets $(\mathrm{mg})$. The calcium level was $12.80 \mathrm{mg}$ in diet 1 (control diets) and $745.40 \mathrm{mg}$ in diet 2 (test diet). Diet I had $7.45 \mathrm{mg}$ iron and $6.13 \mathrm{mg}$ in diet. 2. Zinc was $3.66 \mathrm{mg}$ and $4.35 \mathrm{mg}$ in diets 1 and 2 respectively. $\beta$-carotene was $358.15 \mathrm{RE}$ in diet I and 521.28 $\mathrm{RE}$ in diet 2 .

Table 6. minerals and $\beta$-carotene contents of the formulated diets (mg/100)

\begin{tabular}{lll}
\hline Nutrient & Diet 1 & Diets 2 \\
\hline Calcium & $12.80 \pm 0.2$ & $745.40 \pm 0.02$ \\
Iron & $7.45 \pm 0.01$ & $6.13 \pm 0.01$ \\
Zinc & $3.66 \pm 0.01$ & $4.35 \pm 0.02$ \\
$\beta$-carotene (RE) & 358.15 & 521.28 \\
\hline
\end{tabular}

Key: Mean \pm SD of three determinations; Diet $1=$ control diet with maize and soybean (60:40); Diet $2=$ test diet with maize, soybean and Moringa oleifera leaf $(60: 30: 10)$

Table 7 contains minerals and $\beta$-carotene of the two diets on dry matter basis $(\mathrm{mg} / 100 \mathrm{~g})$. The calcium content of diet 2 was $829.28 \mathrm{mg}$ and $14.36 \mathrm{mg}$ in diet 1 . Diet 1 had iron of $8.32 \mathrm{mg}$ and diet 2 had $6.82 \mathrm{mg}$. The zinc content of the two diets was $4.09 \mathrm{mg}$ and $4.84 \mathrm{mg}$ respectively. The $\beta$ carotene content of diet 1 was $358.15 \mathrm{RE}$ and that of diet 2 was 521.28RE.

Table 7. Minerals and $\beta$-carotene contents of the complementary diets (dry matter basis; $m g / 100 g$ )

\begin{tabular}{lll}
\hline Nutrient & Diet 1 & Diet 2 \\
\hline Calcium & $14.36^{\mathrm{b}}$ & $829.28^{\mathrm{a}}$ \\
Iron & $8.32^{\mathrm{a}}$ & $6.82^{\mathrm{a}}$ \\
Zinc & $4.09^{\mathrm{a}}$ & $4.84^{\mathrm{a}}$ \\
$\beta$-carotene RE & $358.15^{\mathrm{b}}$ & $521.28^{\mathrm{a}}$ \\
\hline
\end{tabular}

Key: Diet $1=$ Control diet with maize and soybean (60:40); Diet $2=$ test diet with maize, soybean and Moringa oleifera leaf (60:30:10); Values of the same nutrients with the same superscript $(\mathrm{a}-\mathrm{a})$ are statistically similar $(\mathrm{P}>0.05)$ and those with different letters $(\mathrm{a}-\mathrm{b})$ are different $(\mathrm{P}<0.05)$. 
The Estimated Daily Requirements: Calcium $=301$ to $421 \mathrm{mg}$; iron $=6$ to $11 \mathrm{mg} ; \quad$ zinc $=2.2$ to $2.4 \mathrm{mg} ; \beta$ carotene $=164$ to $313 \mu \mathrm{gRE}^{[37]}$

Table 8 shows the sensory evaluation of formulated diets (diets 1 and $2=$ control and test diets). The diets had comparable flavour, texture and general acceptability scores but the colour differed $(\mathrm{P}<0.05)$.

Table 8. Sensory evaluation of complementary diets

\begin{tabular}{lll}
\hline Sensory evaluation & Diet 1 & Diet 2 \\
\hline Colour & $8.10^{\mathrm{a}}$ & $7.10^{\mathrm{b}}$ \\
Texture & $7.74^{\mathrm{a}}$ & $7.37^{\mathrm{a}}$ \\
Flavour & $8.03^{\mathrm{a}}$ & $7.57^{\mathrm{a}}$ \\
General acceptability & $7.97^{\mathrm{a}}$ & $7.89^{\mathrm{a}}$ \\
\hline
\end{tabular}

Key: Diet 1 = Control diet : Maize $:$ soybean : $(60: 40)$; Diet $2=$ Test diet: Maize: soybean: Moringa oleifera leaf (60: 30:10); Values with the same letters $(\mathrm{a}-\mathrm{a})$ on the same row are statistically similar $(\mathrm{P}>0.05)$ and those with different letters $(\mathrm{a}-\mathrm{b})$ are different $(\mathrm{P}<0.05)$

Table 9 presents the anthropometric indices of the subjects before and after feeding. There was a significant difference $(\mathrm{p}<0.05)$ between weight before and weight after feeding for the subjects fed diet 2 (the test diet). The length, head circumference and chest circumference of the group fed the test diet were comparable before and after the feeding trial. For the group fed diet 1 (the control diet), weight, length, head circumference and chest circumference were comparable before and after the feeding trial.

Table 10 shows the percentage increase in serum calcium, zinc, iron, $\mathrm{Hb}$, UIBC and TIBC of the subjects before and after feeding. Serum calcium increased with $2.58 \%$ in group 1 fed diet 1 and $2.01 \%$ in group 2 fed diet 2 : There was a significant difference $(\mathrm{P}<0.05)$ in the serum zinc before and after feeding (from 72.75 to $145.80 \mu \mathrm{g} / 100 \mathrm{ml})$ in group 1 with $45.96 \%$ increase. However, zinc level increased in group 2 by $11.68 \%$ (from
142.10 to $150.90 \mu \mathrm{g} / 100 \mathrm{ml})$. Serum iron level increased in both groups 1 and 2 by $2.00 \%$ and $7.23 \%$, respectively. There was $8.96 \%$ increase in the $\mathrm{Hb}$ of group 1 subjects fed diet 1 (the control diet) and $12.34 \%$ of increase in group 2 subjects fed diet 2 (the test diet). Both were statistically different $(\mathrm{P}<0.05)$. Unsaturated iron bending capacity (UIBC) had $15.30 \%$ increases in group 2 and $25.91 \%$ in group 1. Both groups had increased total iron binding capacity (TIBC) level. Group I had $32.55 \%$ and group 2 had $16.01 \%$ increases. However, group 1 is statistically different $(\mathrm{P}<0.05)$ in both UIBC and TIBC.

Table 9. Anthropometric indices

\begin{tabular}{lll}
\hline Parameter & Diet 1 & Diet 2 \\
\hline Weight $(\mathrm{kg})$ & & \\
Before & $8.70^{\mathrm{a}}$ & $8.14^{\mathrm{b}}$ \\
After & $8.79^{\mathrm{a}}$ & $9.01^{\mathrm{a}}$ \\
Increase $(\%)$ & $0.09(0.45 \%)$ & $0.87(9.34 \%)$ \\
Length $(\mathrm{cm})$ & & \\
Before & $72.88^{\mathrm{a}}$ & $69.56^{\mathrm{a}}$ \\
After & $75.63^{\mathrm{a}}$ & $72.33^{\mathrm{a}}$ \\
Increase $(\%)$ & $2.75(3.69 \%)$ & $2.77(3.66 \%)$ \\
Head circumference $(\mathrm{cm})$ & & \\
Before & $44.88^{\mathrm{a}}$ & $44.22^{\mathrm{a}}$ \\
After & $46.25^{\mathrm{a}}$ & $45.56^{\mathrm{a}}$ \\
Increase $(\%)$ & $1.37(0.04 \%)$ & $1.34(2.86 \%)$ \\
Chest circumference $(\mathrm{cm})$ & & \\
Before & $46.00^{\mathrm{a}}$ & $46.33^{\mathrm{a}}$ \\
After & $47.00^{\mathrm{a}}$ & $47.00^{\mathrm{a}}$ \\
Increase $(\%)$ & $1.00(3.61 \%)$ & $0.67(2.81 \%)$ \\
\hline
\end{tabular}

Key: Diet 1: Control diet $=$ Maize and soybean $(60: 40) ;$ Diet 2: test diet $=$ maize, soybean and Moringa oleifera leaf (60: 30: 10); Values with the same letters $(\mathrm{a}-\mathrm{a})$ on the same column are statistically similar $(\mathrm{P}>0.05)$ and those with different letters $(\mathrm{a}-\mathrm{b})$ are different $(\mathrm{P}<0.05)$

Table 10. Serum calcium, zinc, iron Haemoglobin (Hb), unsaturated iron binding capacity (UIBC) and total iron binding capacity (TIBC) of the subjects before and after feeding the two diets

\begin{tabular}{|c|c|c|c|c|c|}
\hline Parameter & Diet 1 & Diet 2 & Parameter & Diet 1 & Diet 2 \\
\hline $\begin{array}{l}\text { Serum calcium } \\
(\mathrm{mg} / 100 \mathrm{ml})\end{array}$ & & & $\mathrm{Hb}(\mathrm{g} / 100 \mathrm{ml})$ & & \\
\hline Before & $10.04^{\mathrm{a}}$ & $10.20^{\mathrm{a}}$ & Before & $9.25^{\mathrm{b}}$ & $8.50^{\mathrm{b}}$ \\
\hline After & $10.34^{\mathrm{a}}$ & $10.39^{\mathrm{a}}$ & After & $10.16^{\mathrm{a}}$ & $9.71^{\mathrm{a}}$ \\
\hline Increase $(\%)$ & $0.30(2.58 \%)$ & $0.19(2.01 \%)$ & Increase $(\%)$ & $0.91(8.96 \%)$ & $1.21(12.34 \%)$ \\
\hline Serum zinc $(1 / \mathrm{g} / 100 \mathrm{ml}$ & & & UIBC $(\mu \mathrm{g} / 100 \mathrm{ml}$ & & \\
\hline Before & $72.75^{\mathrm{b}}$ & $142.10^{\mathrm{a}}$ & Before & $227.50^{\mathrm{a}}$ & $308.90^{\mathrm{a}}$ \\
\hline After & $148.80^{\mathrm{a}}$ & $150.90^{\mathrm{a}}$ & After & $366.00^{\mathrm{a}}$ & $366.40^{\mathrm{a}}$ \\
\hline Increase $(\%)$ & $73.05(45.96 \%)$ & $8.80(11.68 \%)$ & Increase $(\%)$ & $136.50(25.91 \%)$ & $57.50(15.30 \%)$ \\
\hline Serum Iron $\mu / 100 \mathrm{ml}$ ) & & & TIBC $(\mu \mathrm{g} / 100 \mathrm{ml}$ & & \\
\hline Before & $115.90^{\mathrm{a}}$ & $116.0^{\mathrm{a}}$ & Before & $330.90^{b}$ & $413.80^{\mathrm{a}}$ \\
\hline After & $116.10^{\mathrm{a}}$ & $122.6^{\mathrm{a}}$ & After & $494.60^{\mathrm{a}}$ & $489.40^{\mathrm{a}}$ \\
\hline Increase $(\%)$ & $0.20(2.00 \%)$ & $6.6(7.23 \%)$ & Increase $(\%)$ & $163.7(32.55 \%)$ & $75.60(16.01 \%)$ \\
\hline
\end{tabular}

Diet 1: Control diet = Maize and soybean (60:40); Diet 2: test diet = maize, soybean and Moringa oleifera leaf (60: $30: 10)$; Values with the same letters $(\mathrm{a}-\mathrm{a})$ on the same column are statistically similar $(\mathrm{P}>0.05)$ and those with different letters $(\mathrm{a}-\mathrm{b})$ are different $(\mathrm{P}<0.05)$ 


\section{Discussion}

\subsection{Nutrient and Energy Content of the Control and Test Diets}

The protein content of the two diets used in feeding the subjects differed $(\mathrm{P}<0.05)$. The control diet had $15.15 \%$ while the test diet had $11.30 \%$. There was no significant difference between the two diets in fat content $(\mathrm{P}>0.05)$. However, control diet had higher level of fat (30.64\%) than the test diet $(27.20 \%)$. This could be as a result of more soybean in the control diet (40\%) than in the test diet (30\%). This equally confirms soybean as oil seed which contains a lot of fat (21.7\%). The ash for both diets were similar $(\mathrm{P}>0.05)(3.43 \& 3.08 \%)$. Carbohydrate content of diet 2 was significantly $(p<0.05)$ higher. There was no significant difference $(\mathrm{P}>0.05)$ between the control diet and the test diet in energy contents.

The iron, $(8.32 \& 6.82 \mathrm{mg})$ and zinc $(4.09 \& 4.84 \mathrm{mg})$ levels of the two diets were comparable. B-carotene (358.16 \& 521.28RE) level differed. The calcium value of control diet was moderate $(14.36 \mathrm{mg})$. The test diet had a very high value $(829.78 \mathrm{mg})$. This may probably be due to the presence of Moringa oleifera leaves

\subsection{Sensory Evaluation}

There was no significant difference $(\mathrm{P}>0.05)$ between diet 1 (the control diet) and diet 2 (the test diet) in flavour, texture and acceptability scores. Both diets contained fermented maize and soybean basically. Fermentation has been reported to enhance nutritional value, texture, shelf life, aroma and taste of food products ${ }^{[29,30]}$. However, there was significant difference in colour $(\mathrm{p}<0.05)$ of the two diets.

\subsection{Anthropometric Indices}

There was a significant difference $(\mathrm{P}<0.05)$ in the mean weight of the subjects fed the test diet (diets 2) before and after the feeding. The subjects fed the control diet (Diet 1) had similar $(\mathrm{P}>0.05)$ mean weight before and after the 12 week study. This suggests that test diet is nutritionally adequate to support growth and weight gain. The test diet also appears to be nutritionally superior to the control diet. This might be attributed to the addition of Moringa oleifera leaf (a wonder plant) which is rich in multiplicity of nutrients to the test diet. Researchers reported better growth pattern in children fed maize based diet improved by fermentation, addition of legumes (soybean and groundnuts) and fish powder than the usual growth pattern of a cross section of infants in the community who were outside the intervention after a feeding trial of 6 months ${ }^{[31]}$. Onuoha and Okeke did not observe any difference in the weight for age, length for age and weight for length measurements in the children fed their different diets. This was attributed to the short period (4 weeks) of feeding ${ }^{[32]}$. Another group of researchers observed $4.6 \mathrm{~kg}$ gain in weight of their experimental group fed fortified maize meal for 12 months while the control group fed unfortified maize meal gained $2.0 \mathrm{~kg}$. The difference in weight was attributed to addition of fortificants to the $\operatorname{diets}^{[33]}$. West et al demonstrated a significant effect of additional micronutrient on growth in children who were severely vitamin A deficient ${ }^{[34]}$.

\subsection{Biochemical Parameters (a) (Serum $\mathrm{Ca}, \mathrm{Zn}, \mathrm{Fe}$ )}

There was a slight increase in blood calcium level of both groups. One would expect high increase due to the high calcium contents of the diets especially diet 2 . The reason could be due to poor absorption of the calcium. Factors that could limit calcium absorption include dietary fibre from the diets, great excess of phosphorous in the diets, polyphenols (tannins) and Vitamin D deficiency ${ }^{[35]}$. Onuoha and Okeke observed decrease in blood calcium in children which they attributed to low calcium content of the individual diets or lack of vitamin $\mathrm{D}^{[32]}$. The increase in zinc level of both groups was not a surprise since both diets had high zinc content than the requirement of the age group used for this study. However, there was a significant difference $(\mathrm{P}<0.05)$ between blood zinc level before and after feeding in group 1 (control group). This could mean that group 1 subjects absorbed zinc in their diet better than those of group 2.

\subsection{Biochemical Parameters (b) (Haemoglobin (Hb), Unsaturated Iron Binding Capacity (UIBC) and Total Iron Binding Capacity (TIBC)}

The haemoglobin level of children fed both diets (control and test diets) increased but was higher (12.34\%) in group 2 (the experimental group) than $(8.96 \%)$ in group 1 (control group). The reason could be because the Moringa oleifera leaves in diet 2 was high in vitamin C ( 7 times higher than in orange), which enhanced absorption of iron. Another reason could be that the Moringa oleifera leaves in diet 2 were rich in B-carotene (Pro-vitamin A). Northrop-Clewes established an interaction between vitamin $\mathrm{A}$ and iron. The work examined iron and vitamin A status of different communities. Haematological indices and serum retinol in women with anaemia and those without anaemia were measured. There was a positive correlation between serum retinol and haemoglobin in the anaemic group but not in the control ${ }^{[36]}$. The unsaturated iron binding capacity and total iron binding capacity of control group were significantly high indicating low serum iron (table 10). This is in line with Dacie and Lewis who documented that the higher the iron concentration the lower the unsaturated iron binding capacity and vice versa ${ }^{[28]}$.

\section{Conclusion}

This study has shown that fortification of infant complementary food with green leafy vegetable is possible. 
It has equally shown that food-to-food fortification with local foods materials does improve the blood level ( $\mathrm{Hb})$, minerals, vitamins, weight and length of children. It has been proved that Moringa oleifera leaves are nutritious and can be shade-dried and stored all year round and used as required. The sensory evaluation carried out in this study further proved that fermentation increases acceptability of maize and soybean.

\section{Recommendation}

- A similar study should be carried out in a hospital set up to determine the effect of Moringa oleifera leaves in the malnourished children.

- A similar study should equally be carried out with infants that are breastfeeding.

- Moringa oleifera leaves processing and utilization through nutrition education should be encouraged amongst mothers and caregivers.

- Moringa oleifera tree cultivation around homes would ensure availability all year round to reduce micronutrient disease during fruits and vegetables off season.

\section{References}

[1] WHO(2001) The optimal duration of exclusive breastfeeding: report of an expert consultation (WHO/FCH/CAH/01.24) Geneva: March 2001.

[2] UNICEF (2001) Critical control points of complementary food preparation and handling in Eastern Nigeria. Nutrition paper of the month. May 2001.

[3] Asindi, A.A., Ibia, E.O. \& Udo, J.J. (1990). Mortality among Nigerian children. Tropical medical Hygiene, 94, $\begin{array}{llll}152-155 & \text { copyright } & 2004 & \text { from }\end{array}$ http://www.bioline.org.br/requestam 04030

[4] Nigeria Demographic and Health Survey (2003). National Population Commission Federal Republic of Nigeria Abuja, Nigeria. MEASURE DHS, ICF Macro Calverton, Maryland, USA.

[5] Nigeria Demographic and Health Survey (2008). National Population Commission Federal Republic of Nigeria Abuja, Nigeria. MEASURE DHS, ICF Macro Calverton, Maryland, USA,

[6] UNICEF (1998). State of the world children. Oxford University Press Limited. Pp 8-24.

[7] Dewey, K.G. and Brown, K.H. (2003), Update on technical issues concerning complementary feeding of young children in developing countries and implications for intervention programmes. Food and Nutrition Bulletin, 24, 5-28.

[8] WHO (2003). Diet, nutrition and the prevention of chronic diseases. Report of a Joint WHO/FAO Expert Consultative Geneva. 28 January-1 February

[9] WHO (2002): Global forum for child health research; a foundation for improving child health. Switzerland, Geneva
2002. Retrieved May, 2004 from www.who.int/childadolesecenthealth/Newpublication_Healt h/GC/WHO_CFH_02.3PDF

[10] WHO(1998). Complementary Feeding of young children in developing countries: A review of current scientific knowledge. World Health Organization (WHO) Geneva, P. 80

[11] Jakarta (2005). Result of a Nutrition survey on Nias and Simeulue Islands, February, 2005.

[12] ACC/SCN (United Nations Administrative Committee on coordination- subcommittee on Nutrition) (2000). Fourth report on the World Nutrition Situation. ACC/SCN in collaboration with the International Food Policy Research Institute, Geneva, Switzerland.

[13] WHO(2000) Complementary feeding, family foods for breast-fed children. Department of Nutrition for Health and Development WHO. 1-7

[14] $\mathrm{WHO}(2001)$ The optimal duration of exclusive breastfeeding: report of an expert consultation (WHO/FCH/CAH/01.24) Geneva: March 2001.

[15] Ibeanu, V. and Obizoba, I. C. (2004). Consumption profile of fermented and germinated Foods in Anambara and Enugu states and the effect of ARF on complementary gruel formulations. Research in the department Home Science, Nutrition and Dietetics, University of Nigeria Nsukka, Nigeria.

[16] Nnam, N.M. (1994). Effects of village processing methods on the nutritional value of African Yam bean and cowpea flours. African Indigenous Technology, 9, 87-93.

[17] Nnam, N. M. (1998). Nitrogen and mineral utilization of young children fed blends of fermented or unfermented corn (Zea mays L.) African yam bean (Sphenostylis stenocarpa) and cowpea (Vigna unguiculata), Ecology of Food Nutrition $38,21-34$

[18] Nnam, N.M. (2000). Chemical Evaluation of Multimixes formulated from some local staples for use as complementary foods in Nigeria. Plant Food for Human Nutrition, 55, 255-263.

[19] Nnam, N.M. (2001). Comparison of the protein nutritional value of food blends based on sorghum, bambara groundnut and sweet potatoes. International Journal of Food Science and Nutrition, 52, 25-29.

[20] Nnam, N.M. (2002). Evaluation of complementary food based on maize, groundnut, pawpaw and mango flour blends. Nigerian Journal of Nutrition Sciences 23(182): 816.

[21] Obizoba, I.C. (1989). Nutritive quality of blends of corn with germinated cowpea (Vigna unguicculata), pigeon pea, (Cajanus cajan), and bambara groundnut (Voandzia subterranean). Cereal Chemistry, 67, 230-232

[22] Asma, M.A. Babikar, E., Fadil, E.L. \& Abdullahi, H.T.. (2006). Development of weaning food from sorghum supplemented with legumes and oil seeds. Food and Nutrition Bulletin, 27:1.

[23] A.O.A.C.(1995). Association of Official Analytical Chemists. Official methods of analysis $15^{\text {th }}$ ed. Washington DC, U.S.A pg 40-49. 
[24] A.O.A.C.(2005). Official Methods of Analysis, Association of official Analytical Chemistry, $16^{\text {th }}$ ed. Washington DC, U.S.A. p. 19

[25] A.A.C.C. (1992) Journal of American Association of Cereal chemistry approval methods 3: 222

[26] Ranjiham, S.K. and Gapal, K. (1980). Wet Chemical digestion of biological materials for mineral analysis. In: Laboratory Manual for Nutrition Research (pp.83-84) New Delhi: Vikas publishing House

[27] Kleinman, R.E. (2009). Calcium, phosphorus and magnesium. In: Pediatric Nutrition Handbook. $6^{\text {th }}$ ed. Kleinman. American Academy of Pediatrics, pp.387-401.

[28] Dacie, J. V. and Lewis, S. M. (1984). Practical Haematology. Sixth edition. Churchill Livingstone Longmans Singapore Publishers Limited.

[29] Yadan, S. and Kheterpaul, N. (1994). Indigenous legume fermentation: Effect of anti-nutrients and in-vitro digestibility of starch and protein. Journal of food Chemistry, $50,403-406$

[30] Steinkraus, K.H., Pederson, C.S., Nellis, L.F. and Cullen, R.E. (1995): Hand book of indigenous fermented foods. Marcel. Dekar inc. New York.

[31] Lartey, A., Manu, A., Brown, K.H., Pearson, J.M. \& Dewey (1999). A randomized community- based trial of the effect of improved centrally processed complementary foods on the growth and micronutrient status of Ghanian infants from 6-12 months of age. American Journal of Clinical Nutrition, $70,391-404$

[32] Onuoha, N. O. and Okeke C. (2007). Development of low cost micronutrient-rich complementary foods based on locally available food commodities and commonly consumed diets. Ph.D thesis, University of Nigeria Nsukka: Nigeria.

[33] Nesamvuni, A.E., Vorster, H.H., Margatts, B.M. and Kruger, A (2005). Fortification of maize meal improved nutritional status of 1-3 years old children. Public Health Nutrition, 8, 461-467.

[34] West, K.P., Leclerg, S.C., Shrestha, S.R., Wu, L.S., Pradham, F.K. \& Khartry, S.K. (1997). Effects of vitamin A on growth of vitamin A deficient children: Field studies in Nepal. Journal of Nutrition, 127, 1957-1965.

[35] Akinyele, I.O. (2002). Calcium contents of Nigerian foods. Nutritional rickets in Nigeria Children: The way forward. Nestle Nutrition pp 63-65.

[36] Northrop - Clewes, (1999). Vitamin A and other micronutrients: Biological interactions and integrated interventions. IVACG. Sight and Life Newsletter 2, 3-26.

[37] Brown, K.H., Allen, L.H. \& Dewey, K.G. (1997). Complementary feeding of young children in developing countries. A review of current scientific knowledge WHO/UNICEF forthcoming, 1997. 